\title{
Systemic Financial Distress and Auction-Based Bankruptcy Reorganization
}

\author{
by \\ Donald B. Hausch \\ School of Business \\ University of Wisconsin \\ Madison, WI 53706 \\ and \\ S. Ramachandran \\ The World Bank \\ 1818 H Street \\ Washington, DC $20433^{1}$
}

November 1999

\begin{abstract}
Most bankruptcy procedures attempt to reorganize a financially-distressed firm's debts to a serviceable level through negotiations overseen by courts. Markets have been suggested as an alternative to such negotiations. This paper develops such a market-based approach that is appropriate if claimants are severely cash-constrained and there is merit in having existing owners-managers remain in control.

The scheme arranges creditors in a queue to be serviced in sequence from the firm's operating cash flows. Creditors bid for their position in this queue, and those accepting a greater proportionate reduction in the face value of their claims are placed ahead of the others. A pre-existing hierarchy of claims is honored by having claimants bid for their positions within the relevant segment of the queue. No one in the queue (including owners who are last) is paid anything until the (reduced) debts of the first in line are fully discharged using the firm's operating cash surpluses. The queue then moves up and the next claimant in line is serviced.

The paper shows that, in equilibrium, the aggregate debts of the firm are reduced to a level that is more serviceable and that provides the owner-manager with a positive expected residual return. We discuss the appropriateness of this scheme to situations of systemic financial distress, including the East Asian crisis.

${ }^{1}$ (608)-262-2535 dhausch@bus.wisc.edu (202)-473-9489 sramachandran@worldbank.org
\end{abstract}




\title{
Systemic Financial Distress and Auction-Based Bankruptcy Reorganization
}

by

\author{
Donald B. Hausch and S. Ramachandran ${ }^{1}$
}

\section{Introduction}

The basic goal of a bankruptcy process is to reorganize the liabilities of the firm if it is deemed to be viable or to liquidate it in an orderly manner if it is not. Courts supervise the process to prevent individual creditors from "grabbing" assets or garnering proceeds out of turn and to prevent holdouts from getting an unfair advantage. Countries differ in their bankruptcy procedures but all have their critics. $^{2}$

The 1978 U.S. Bankruptcy Code, for instance, allows firms to be either liquidated under Chapter 7 or reorganized under Chapter 11. Two common criticisms of Chapter 7 are that (1) viable firms may be needlessly dismantled, and (2) sales proceeds would be meagre when the most likely buyers of industryspecific assets are buffeted by the same adverse economic developments as the bankrupt firm (Shleifer and Vishny, 1992). Chapter 11 is a structured negotiation among current managers, equityholders, and creditors, with the outcome being an agreement on a different payment stream than what was originally contracted. The new agreement can include a postponement of interest payments, a reduction in the debt, or a swapping of debt for equity. While all of these changes are possible without filing for bankruptcy, filing limits the ability of dissenting minority creditors to block a reorganization and an automatic stay temporarily allows the debtor to halt payments on some or all of its debts (see LoPucki and Whitford, 1993). Chapter 11 is often criticized as (1) too lengthy with high legal and administrative costs, (2) having a pro-management bias, and (3) violating the absolute priority of claims (because secured creditors cannot immediately seize assets and because payouts to junior claimants are common despite reductions in the claims of senior claimants).

\footnotetext{
${ }^{1}$ University of Wisconsin, Madison and the World Bank, respectively.

2 Berkovitch and Israel (1999) show that a country's optimal bankruptcy procedure is a function of the ability of creditors to gain information about the firm and the ability of managers to exploit their private information.
} 
Bebchuk (1988) proposed a market-based alternative to a negotiated bankruptcy. Using Black and Scholes' original insight that equity is a call option on the firm's assets with an exercise price equal to the debt that is owed, Bebchuck proposed working up the hierarchy of claims. Starting with the most junior claimant (namely, equity), each claimant class is given a choice of either paying off all the more senior claimants in full or having its own claims extinguished. Whichever class pays off all the more senior claimants becomes the firm's new owners. Bebchuk's proposal respects the absolute priority of the claims and results in an all-equity firm. ${ }^{3}$

Bebchuk's proposal allows only existing claimants (shareholders and creditors) to bid. Outsiders may run the firm better, thereby raising its value; so Aghion, Hart and Moore (1992, hereafter AHM) proposed allowing outsiders to both bid and to specify different ways the existing claims would be paid. For example, creditors may propose restructuring the existing debt, while an outside bidder (e.g. a firm in a similar business) may offer to merge and replace debt with equity in the merged entity. Different classes of claimants would value the bids differently (e.g. senior claimants would tend to prefer offers with a low variance to the returns), so AHM propose "homogenizing" the claimants (possibly through Bebchuk's scheme), so that the various offers could be voted on.

While AHM's proposal is more suitable when outsiders could run the firm better, it may require bidders to pay in cash and it may involve cash payments to achieve homogenized bidders prior to the vote. ${ }^{4}$ Thus, this procedure may be adversely affected by systemic bankruptcy, since potential bidders are often cash constrained and capital markets are typically functioning imperfectly. Also, the scale of the financial distress may simply preclude replacing many of the managers. Finally, even if a wholesale change in management were feasible, it is unlikely to be appropriate or desirable in the same way that is might be for an isolated bankruptcy. This is because an economic crisis that is accompanied by a large

\footnotetext{
${ }^{3}$ The firm could borrow through a separate transaction that could occur simultaneously if all the claimants in that class agree to accept pro rata fractions of each class of liabilities in the desired new financial structure. 4 Although, Hart, La Porta Drago, Lopez-de-Silanes, and Moore (1997) offer a variation on AHM that accommodates cash-constrained claimants.
} 
depreciation of the currency and a sharp increase in interest rates reveals little about the abilities of management, and therefore calls for a more pro-debtor stance (see Stiglitz, 1999)

\section{East Asia's Systemic Problems}

Firms in the crisis countries of East Asia are heavily indebted. They were highly leveraged before the crisis, and leverage has increased since. Debts were often denominated in foreign currency even for non-exporters. Interest rates have seen sharp increases and currency values have fallen in the foreign exchange market, but even if interest rates and exchange rates were restored to their pre-crisis levels, the debts of many firms have now mushroomed to levels which may not be serviceable.

\section{Table 1}

\section{Salient Corporate Statistics}

\begin{tabular}{|c|c|c|c|c|c|}
\hline & Indonesia & Korea & Malaysia & Philippines & Thailand \\
\hline $\begin{array}{l}1998 \text { to } 1996 \text { Real } \\
\text { GDP ratio }\end{array}$ & 0.88 & 1.00 & 1.00 & 1.05 & 0.92 \\
\hline 1998 GDP & $\$ 105 \mathrm{~b}$ & $\$ 309$ b. & $\$ 69.4$ b. & $\$ 68 \mathrm{~b}$. & $\$ 121 \mathrm{~b}$. \\
\hline $\begin{array}{l}\text { Nominal Exchange } \\
\text { Rate ratio: mid-1999 } \\
\text { to mid } 1997\end{array}$ & 2.75 & 1.31 & 1.5 & 1.43 & 1.44 \\
\hline $\begin{array}{l}\text { Capacity utilization } \\
\text { (mid-1998) }\end{array}$ & $58 \%$ & $71 \%$ & $65 \%$ & $68 \%$ & $60 \%$ \\
\hline $\begin{array}{l}\text { Total Corporate Debt } \\
\text { (b. US\$ equivalent) }\end{array}$ & 118.0 & 444.0 & 120.2 & 47.5 & 195.7 \\
\hline Of which external & 67.1 & 64 & 40 & 23.3 & 32.5 \\
\hline $\begin{array}{l}\text {...domestic debt } \\
\text { (b. US\$ equiv). }\end{array}$ & 50.9 & 380.0 & 80.2 & 24.2 & 163.2 \\
\hline $\begin{array}{l}\text { Banking Sector's } \\
\text { External Debt } \\
\text { (b US\$) }\end{array}$ & 50.3 & 72.4 & 23.0 & 17.8 & 46.8 \\
\hline $\begin{array}{l}\text { Debt to Equity ratio } \\
1996\end{array}$ & 2.0 & 3.5 & 1.1 & 1.4 & 2.4 \\
\hline
\end{tabular}

${ }^{1}$ World Bank survey of firms (mid-1998)

The firms have been generally well run. While total factor productivity appears to have been declining in recent years, making East Asia's growth less miraculous than was earlier believed, few doubt that firms' managers (who are very closely linked to the controlling owners) are generally competent and able to adapt to the new situation: there are vigorous attempts to restore the firms' profitability. Even so, debts that cannot be serviced must be renegotiated, and this is not occurring rapidly. The status quo erodes the owner-managers' incentives to operate the firm efficiently because any increase in firm value 
accrues entirely to the creditors. Put differently, the owners' call options are now far "out of the money" because the exercise price far exceeds the asset value of the firm.

Countries have promulgated new bankruptcy laws or amended old ones and are improving their courts' functioning. It is nevertheless clear that the courts are - and should be - designed to deal with the normal mortality rate of firms, not those stemming from an economy-wide scale ("systemic crisis"). Furthermore, it would be foolhardy for most creditors to take over and try to operate the affected firms: they lack the skill and cannot oversee the managers that do. Managers have valuable firm-specific human capital and are beholden (and often related) to the owners.

What is needed therefore is a quick way for the debts to be reduced to sustainable levels without disrupting existing management which is restructuring operations in response to the changed markets. Bankruptcy negotiations would stall if owner-managers fear a loss of control, and courts are too inexperienced to nudge discussions along. Furthermore, governments have intervened heavily in the banking system and their agencies are now major creditors to the privately owned firms. There is a considerable risk that debt negotiations could take on a political color. Market based alternatives to court proceedings are therefore very attractive.

\section{The Need for a Different Scheme}

The existing proposals in the literature, ingenious though they are, may be unsuited to the East Asian circumstances. Credit markets work poorly especially now: domestic banks are largely bankrupt (governments are restructuring them) and access to foreign credit has been disrupted. With potential domestic bidders cash constrained, large-scale sales to foreigners could generate a backlash of public sentiment, especially in countries with recent and unpleasant colonial experiences. Even if these problems were surmountable, outsiders (whether domestic or foreign) face an acute information asymmetry problem: firms have been remarkably coy about divulging their finances to their own creditors, let alone to unrelated parties even if they were potential bidders. Therefore, serious problems face schemes relying on outside bidders (as in the AHM proposal) or having junior claimants raise additional cash (as in the Bebchuck proposal). 


\section{The Proposed ACCORD}

This paper develops a non-cash auction based scheme called ACCORD (for Auction based Creditor Ordering by Reducing Debts). Creditors bid the reduction in the claims they are willing to accept, and their bids arrange them in a queue to be serviced in sequence. Those willing to accept the greatest proportionate reduction are placed ahead of the others in the queue. Creditors are then serviced sequentially from the operating cash surplus of the firm which owners continue to control and operate.

Note that all creditors remain creditors; but those that forgive proportionately more have their (reduced) debts fully discharged before those who forgave less. Creditors who believe the firm to be worth little would be willing to forgive a larger proportion of their claim to be sure of obtaining at least something before the funds run out. Conversely, creditors who think that the firm's difficulties are only temporary would forgive little, and wait (further behind in line) for their turn to receive payments. The original equity-holders (i.e. the most junior claimants) do not bid and continue to own and operate the firm, obtaining any residual that may be left.

\section{The Structure of the Paper}

After this introduction, section 2 describes the basic version of the ACCORD when equally senior creditors share a common belief about the probability distribution surrounding the value of the firm. The equilibrium bidding strategies are derived, and the resulting equilibrium is shown to reduce debts to a more serviceable level. The equilibrium outcome of ACCORD gives the owners a positive expected residual return which, compared to the status quo, improves their incentive to operate the firm efficiently (i.e. their call options on the firm would not be way out of the money).

Section 3 discusses extensions to allow for an initial seniority structure of the debt and for creditors with heterogeneous beliefs about the value of the firm. It also considers how to treat the government when it is a creditor. Concluding remarks appear in section 4.

\section{The ACCORD Scheme: “Auctions Speak Louder than Words"}


Under the proposed ACCORD, each creditor bids the reduction in the face value of the debt that they are willing to accept, and their claim is reduced by this proportion. The reduced claims are arranged in order of the proportion reduced, with the resulting queue headed by the creditor with the greatest proportionate reduction. ${ }^{5}$ Unlike the servicing of debts with the usual seniority structure (who all receive periodic interest payments), creditors are paid only if they reach the head of the queue. When the (reduced) debts of the creditor who is currently the first in line are fully discharged, that creditor exits the queue and the remaining creditors all move up one position. Creditors therefore progress forward in the queue and are paid if and only if they reach the head of the queue.

ACCORD requires a creditor to choose between accepting a smaller fraction of their (original) debt but receiving payment sooner (i.e. with a higher probability) and waiting longer for a higher payment. A creditor who offers no reduction (or does not bid at all) is placed at the back of the queue, but ahead of the owners, who as equity-holders, continue to control and operate the firm and obtain any residual after all the debts are discharged.

\section{Two Illustrative Examples}

Consider a firm whose assets have an expected market value of $\$ 100$ and suppose that there are two creditors, each owed an amount that exceeds $\$ 50$, so that the firm is in financial distress. In this section, we assume that both creditors are equally senior and hold a common belief about the firm's value.

We now consider two examples to illustrate equilibrium bidding under ACCORD. In both, the creditor who forgives more of the debt becomes the senior claimant and the original equity-holders remain residual claimants.

\section{Example 1: $\quad$ No Uncertainty}

We first suppose that it is commonly known that the true value of the firm is $\$ 100$ with certainty. Let the bid $b_{i}$ represent the new face value of the debt that creditor $i=1,2$ offers in the auction, so that a

\footnotetext{
${ }^{5}$ If there are different classes of creditors initially, the ordering of the classes is unchanged and the bids within each class are arranged according to the reductions bid. This is discussed in section 3 .
} 
lower bid means more forgiveness. The unique pure-strategy Nash equilibrium is $b_{1}=b_{2}=50$ (i.e., both offer a new face value of 50). As a result, the junior claimant is determined by some tie-breaking rule and, whether junior or senior, a creditor receives a certain payoff of 50 .

It is easily seen that $b_{1}=b_{2}=50$ is a Nash equilibrium. To show that there are no other purestrategy equilibria, consider an equilibrium candidate in which, say, creditor 1 bids $b_{1} \neq 50$. First suppose that $b_{1}<50$. Then creditor 2 optimally responds with $b_{2}=100-b_{1}$, to which $b_{1}$ is not a best response for bidder 1 . Second, consider $a$ bid $b_{1}>50$. Only if $b_{2}=100-b_{1}$ can this $b_{1}$ be best for bidder 1 , but such a $b_{2}$ cannot be an optimal response for bidder $2{ }^{6}$

\section{Example 2: $\quad$ With Uncertainty}

Suppose that the value of the firm could be low $(\mathrm{L})$ or high $(\mathrm{H})$, with $\mathrm{H}>100>\mathrm{L}>0$. Suppose that these two outcomes are equally likely. Since the firm's expected value is 100 , then $\mathrm{H}=200-\mathrm{L}$. We first show that $b_{1}=b_{2}=50$ is not an equilibrium. To do so, consider two cases if creditor 1 does choose $\mathrm{b}_{1}=50$.

First, suppose $\mathrm{L} \geq 50$. Bidding $\mathrm{b}_{2}=50$ will result in a tie, and creditor 2 will be randomly selected to be either senior or junior creditor. If senior, creditor 2 receives 50 with certainty. If junior, creditor 2 receives an expected return of $1 / 2(L-50)+1 / 2(50)=1 / 2 L<50$. Thus, creditor 2's average return from also forgiving 50 percent is strictly less than 50. Creditor 2 prefers bidding $b_{2}=100$ (i.e., no forgiveness), for an expected return as junior claimant of $1 / 2(\mathrm{~L}-50)+1 / 2(H-50)=50$.

The second case has $\mathrm{L}<50$. Creditor 2's expected return from bidding $\mathrm{b}_{2}=50$ is $1 / 2(\mathrm{~L})+1 / 2(50)<$ 50 if chosen to be senior creditor and $1 / 2(0)+1 / 2(50)=25$ if junior. Thus, creditor 2 expects a return strictly less than 50 . Creditor 2 prefers to bid $b_{2}=100$, which guarantees junior status and an expected return of $1 / 2(0)+1 / 2(100)=50$.

\footnotetext{
${ }^{6}$ Note how the continuum of pure-strategy equilibria to the Divide-the-Dollar Game is reduced to a unique equilibrium with the introduction of the seniority structure.
} 
A pure strategy equilibrium does not exist for this example. If creditor 1 forgives a lot, then creditor 2 prefers to forgive nothing; but if creditor 1 forgives little, then creditor 2 will forgive slightly more to become the senior creditor. We now determine the mixed-strategy equilibrium.

Let a bid b represent the new (reduced) face value of the debt that is offered by the creditor (i.e., level of forgiveness $=$ original face value $-b)$. Define:

$$
\begin{aligned}
& \mathrm{G}_{1}\left(\mathrm{~b} ; \mathrm{c}_{1}\right)=2+\frac{\mathrm{c}_{1}}{\sqrt{2 \mathrm{~b}-\mathrm{L}}}, \\
& \mathrm{G}_{2}\left(\mathrm{~b} ; \mathrm{c}_{2}\right)=\mathrm{c}_{2}+\frac{\mathrm{b}}{\mathrm{L}}, \\
& \mathrm{G}_{3}\left(\mathrm{~b} ; \mathrm{c}_{1}, \mathrm{c}_{2}\right)=2+\frac{\mathrm{c}_{2}}{\sqrt{2 \mathrm{~b}-100}}-\frac{\mathrm{c}_{1}}{4 \sqrt{2 \mathrm{~b}-100}} \cdot \sin ^{-1}\left[\frac{500-3 \mathrm{~L}-4 \mathrm{~b}}{300-3 \mathrm{~L}}\right], \\
& \mathrm{G}_{4}\left(\mathrm{~b} ; \mathrm{c}_{2}, \mathrm{c}_{3}\right)=\frac{400+2 \mathrm{~L}-\mathrm{b}}{3 \mathrm{~L}}+\mathrm{c}_{2}+\frac{\mathrm{c}_{3}}{\sqrt{2 \mathrm{~b}-200+2 \mathrm{~L}}}, \\
& \mathrm{G}_{5}\left(\mathrm{~b} ; \mathrm{c}_{1}, \mathrm{c}_{4}\right)=\frac{3}{2}+\frac{\mathrm{c}_{4}}{\sqrt{2 \mathrm{~b}-200+2 \mathrm{~L}}}-\frac{\mathrm{c}_{1}}{2 \sqrt{2 \mathrm{~b}-200+2 \mathrm{~L}}} \cdot \sin ^{-1}\left[\frac{600-5 \mathrm{~L}-4 \mathrm{~b}}{200-\mathrm{L}}\right] .
\end{aligned}
$$

Also, define $\mathrm{L}^{*}$ as the solution to:

$$
2 \sqrt{\frac{2 \mathrm{~L}-100}{400-5 \mathrm{~L}}}+\sin ^{-1}\left[\frac{500-7 \mathrm{~L}}{300-3 \mathrm{~L}}\right]=2 \sqrt{2}+\sin ^{-1}(1 / 3)
$$

(I.e., $\left.L^{*} \approx 76.95\right)$

The symmetric Bayesian-Nash equilibrium is for each creditor to independently draw $b$ from an interval $[\underline{b}, \bar{b}]$ according to a cumulative probability distribution, $G(b)$. Since the other creditor will not bid less than $\underline{b}$, there is no benefit to bidding more than $H-\underline{b}$. In fact, we show that $\bar{b}=H-\underline{b}$. Thus, $\underline{b}<$ $1 / 2 \mathrm{H}<\overline{\mathrm{b}}$. There are four cases of $\mathrm{L}$ to consider in specifying the equilibrium: i) $\underline{b}<1 \frac{1}{2} \mathrm{H}<\overline{\mathrm{b}}<\mathrm{L}$; ii) $\underline{\mathrm{b}}<$ $1 / 2 \mathrm{H}<\mathrm{L}<\overline{\mathrm{b}}$; iii) $\mathrm{L}<\underline{\mathrm{b}}<\mathrm{L}<1 / 2 \mathrm{H}<\overline{\mathrm{b}}$; and iv) $\mathrm{L}<\underline{\mathrm{b}}<1 / 2 \mathrm{H}<\overline{\mathrm{b}}$. The symmetric Bayesian-Nash equilibrium is as follows:

Case 1: $\quad \mathrm{L}^{*}<\mathrm{L}<100$ 


$$
G(b)= \begin{cases}G_{1}\left(b ; c_{1}\right) & \text { for b } 0[\underline{b}, 1 / 2 H] \\ G_{3}\left(b ; c_{1}, c_{2}\right) & \text { for b } 0[1 / 2 H, \bar{b}],\end{cases}
$$

where $\{\mathrm{c} 1, \mathrm{c} 2, \underline{\mathrm{b}}, \overline{\mathrm{b}}\}$ solves $\mathrm{G}_{1}\left(\underline{\mathrm{b}} ; \mathrm{c}_{1}\right)=0, \mathrm{G}_{1}\left(1 / 2 \mathrm{H} ; \mathrm{c}_{1}\right)=\mathrm{G}_{3}\left(1 / 2 \mathrm{H} ; \mathrm{c}_{1}, \mathrm{c}_{2}\right), \mathrm{G}_{3}\left(\overline{\mathrm{b}} ; \mathrm{c}_{1}, \mathrm{c}_{2}\right)=1$, and $\underline{\mathrm{b}}+\overline{\mathrm{b}}=\mathrm{H}$.

Case 2: $\quad 200 / 3 \leq \mathrm{L} \leq \mathrm{L}^{*}$

$$
G(b)= \begin{cases}G_{1}\left(b ; c_{1}\right) & \text { for } b 0[\underline{b}, 1 / 2 H] \\ G_{3}\left(b ; c_{1}, c_{2}\right) & \text { for b } 0[1 / 2 H, L] \\ G_{5}\left(b ; c_{1}, c_{3}\right) & \text { for b } 0[L, \bar{b}],\end{cases}
$$

where $\left\{\mathrm{c}_{1}, \mathrm{c}_{2}, \mathrm{c}_{3}, \underline{\mathrm{b}}, \overline{\mathrm{b}}\right\}$ solves $\mathrm{G}_{1}\left(\underline{\mathrm{b}} ; \mathrm{c}_{1}\right)=0, \mathrm{G}_{1}\left(1 / 2 \mathrm{H} ; \mathrm{c}_{1}\right)=\mathrm{G}_{3}\left(1 / 2 \mathrm{H} ; \mathrm{c}_{1}, \mathrm{c}_{2}\right), \mathrm{G}_{3}\left(\mathrm{~L} ; \mathrm{c}_{1}, \mathrm{c}_{2}\right)=\mathrm{G}_{5}\left(\mathrm{~L} ; \mathrm{c}_{1}, \mathrm{c}_{3}\right)$,

$\mathrm{G}_{5}\left(\overline{\mathrm{b}} ; \mathrm{c}_{1}, \mathrm{c}_{3}\right)=1$, and $\underline{\mathrm{b}}+\overline{\mathrm{b}}=\mathrm{H}$.

Case 3: $\quad 100 /\left(1+2^{1 / 3}\right) \leq \mathrm{L} \leq 200 / 3$

$$
G(b)= \begin{cases}G_{1}\left(b ; c_{1}\right) & \text { for b } 0[\underline{b}, L] \\ G_{2}\left(b ; c_{1}, c_{2}\right) & \text { for b } 0[L, 1 / 2 H] \\ G_{4}\left(b ; c_{2}, c_{3}\right) & \text { for b } 0[1 / 2 H, H-L] \\ G_{5}\left(b ; c_{1}, c_{4}\right) & \text { for b } 0[H-L, \bar{b}],\end{cases}
$$

where $\left\{\mathrm{c}_{1}, \mathrm{c}_{2}, \mathrm{c}_{3}, \mathrm{c}_{4}, \underline{\mathrm{b}}, \overline{\mathrm{b}}\right\}$ solves $\mathrm{G}_{1}\left(\underline{\mathrm{b}} ; \mathrm{c}_{1}\right)=0, \mathrm{G}_{1}\left(\mathrm{~L} ; \mathrm{c}_{1}\right)=\mathrm{G}_{3}\left(\mathrm{~L} ; \mathrm{c}_{1}, \mathrm{c}_{2}\right), \mathrm{G}_{3}\left(1 / 2 \mathrm{H} ; \mathrm{c}_{1}, \mathrm{c}_{2}\right)=\mathrm{G}_{4}\left(1 / 2 \mathrm{H} ; \mathrm{c}_{2}, \mathrm{c}_{3}\right), \mathrm{G}_{4}(\mathrm{H}-$ $\left.\mathrm{L} ; \mathrm{c}_{2}, \mathrm{c}_{3}\right)=\mathrm{G}_{5}\left(\mathrm{H}-\mathrm{L} ; \mathrm{c}_{1}, \mathrm{c}_{4}\right), \mathrm{G}_{5}\left(\overline{\mathrm{b}} ; \mathrm{c}_{1}, \mathrm{c}_{4}\right)=1$, and $\underline{\mathrm{b}}+\overline{\mathrm{b}}=\mathrm{H}$.

Case 4: $\quad 0<\mathrm{L} \leq 100 /\left(1+2^{1 / 3}\right)$

$$
G(b)= \begin{cases}G_{2}\left(b ; c_{2}\right) & \text { for b } 0[\underline{b}, 1 / 2 H] \\ G_{4}\left(b ; c_{2}, c_{4}\right) & \text { for b } 0[1 / 2 H, \bar{b}],\end{cases}
$$

where $\left\{\mathrm{c}_{2}, \mathrm{c}_{4}, \underline{\mathrm{b}}, \overline{\mathrm{b}}\right\}$ solves $\mathrm{G}_{2}\left(\underline{\mathrm{b}} ; \mathrm{c}_{2}\right)=0, \mathrm{G}_{2}\left(1 / 2 \mathrm{H} ; \mathrm{c}_{2}\right)=\mathrm{G}_{4}\left(1 / 2 \mathrm{H} ; \mathrm{c}_{2}, \mathrm{c}_{2}\right), \mathrm{G}_{4}\left(\overline{\mathrm{b}} ; \mathrm{c}_{2}, \mathrm{c}_{4}\right)=1$, and $\underline{\mathrm{b}}+\overline{\mathrm{b}}=\mathrm{H}$. 
The proof is in Appendix 1. We now consider several features of the equilibrium. First, in all four cases, the creditors are indifferent among the bids on $[\underline{b}, \bar{b}]$. Bidding $\underline{b}$ guarantees the creditor both senior status and, for cases 1-3, guarantees a payment of $\underline{b}$, since it can be shown that $L>\underline{b}$ for these three cases. In case $4, \mathrm{~L}<\underline{\mathrm{b}}$, so expected payment is $1 / 2 \mathrm{~L}+1 / 2 \underline{b}$. Figure 1 illustrates the range of bids, $[\underline{b}, \bar{b}]$, as $L$ varies from 0 to 100 . Second, the maximum value of $\bar{b}$ is 111.5 . Thus, our analysis implicitly assumes that the original face value of the debt owed to each creditor exceeds $\$ 111.50$ (because creditors cannot be permitted to bid a negative level of forgiveness). If each creditor is owed less than $\$ 115.50$, however, the analysis needs to be slightly modified, but the results are qualitatively the same. Third, for L close to zero (which means $\mathrm{H}$ is near 200), bids are in a small range around 100, which is roughly the value of each creditor's claim were it known that the outcome would be H with certainty. Thus, in effect, the creditors essentially ignore the L outcome, because its value is so low, and focus on the $\mathrm{H}$ outcome. For $\mathrm{L}=100$, the firm is worth 100 with certainty (since $\mathrm{H}=100$, too), so, from Example 1 , creditors bid 50 .

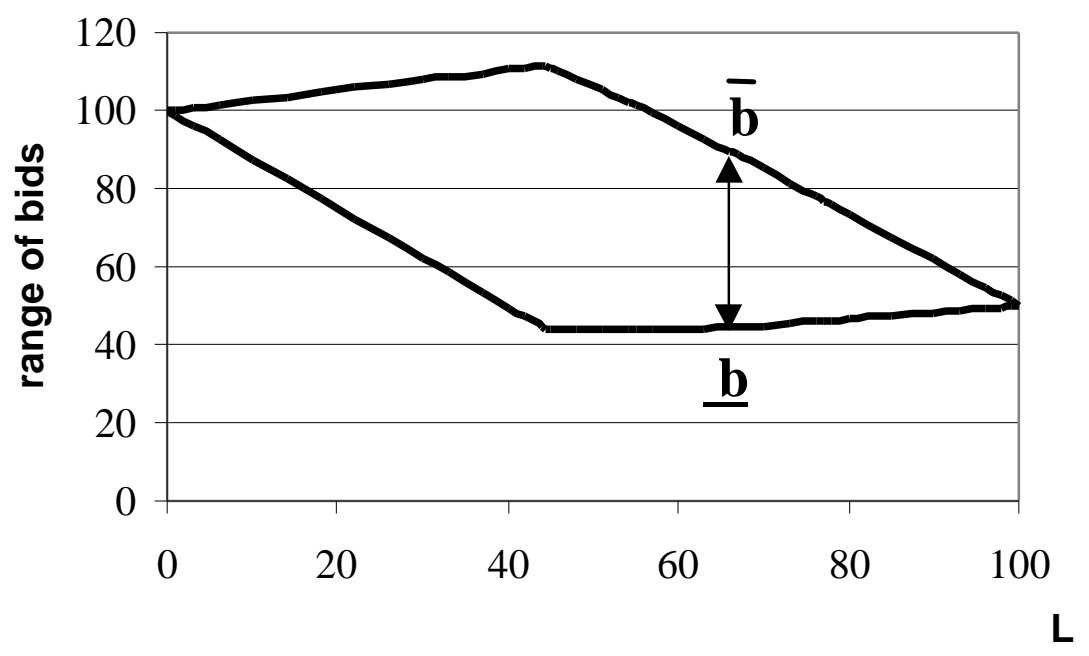

Figure 1: For Example 2, the range of bids, $[\underline{b}, \bar{b}]$, as L varies from 0 to 100. (Recall that $\mathrm{H}=200-\mathrm{L}$, so $\mathrm{H}$ varies from 200 to 100 .)

Since the expected value of the firm is $1 / 2(\mathrm{~L}+\mathrm{H})$, absolute priority would requires that each creditor receives $1 / 4(\mathrm{~L}+\mathrm{H})$. It can be shown that, for all cases $1-4$, each creditor's equilibrium expected 
return is less than $1 / 4(\mathrm{~L}+\mathrm{H})$, though. As a consequence, the owner-manager's equity position has a positive expected value. Figure 2 illustrates the expected value of the equity as L varies from 0 to 100 (and $\mathrm{H}$ varies from 200 to 100). Notice that as L increases from 0, the owner-manager's expected return increases. Beyond about $\mathrm{L}=55$, though, this expected return decreases. To understand this reversal, consider the extreme case of $\mathrm{L}=0$ and $\mathrm{H}=200$, for which the variance of the value is highest. In this case, both creditors bid $b=100$ (i.e., no forgiveness), for an expected return of 100 with probability $1 / 2$, which leaves zero expected return for the owner-manager. Bidding $b=100$ is what the creditors would bid if the value of the firm was known to be 200 with certainty. As discussed above, the bidding ignores the event that the firm value is zero, since no value is realized in that event. This result that the owner-manager's expected return decreases as uncertainty increases is partly an artifact of the example's two-point distribution. This is seen in section 3 with an example of firm value that is uniformly distributed.

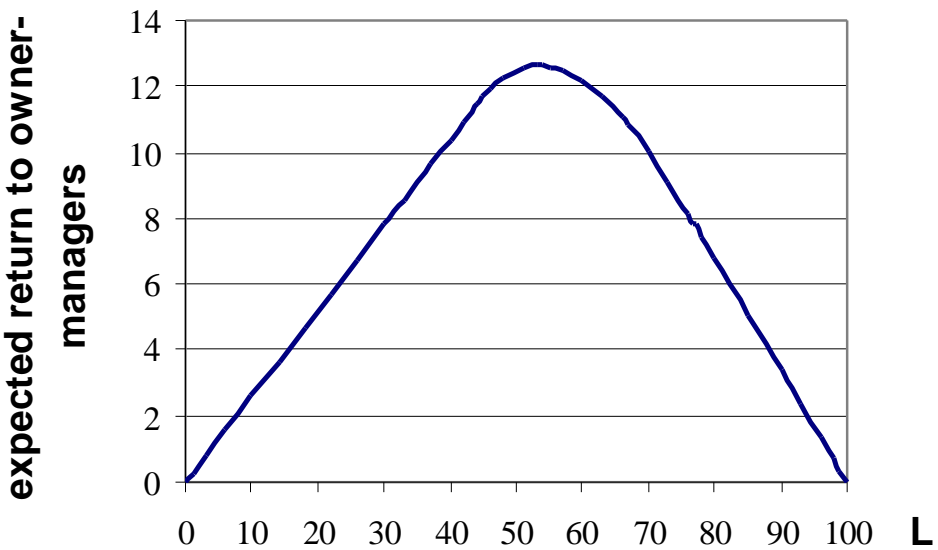

Figure 2: For Example 2, the expected return to the owner-managers following the ACCORD scheme, as L ranges from 0 to 100 . Since the expected value of the firm is 100 for all values of $\mathrm{L}$, the expected return to creditors $=100-$ expected return to owner-managers.

Despite the owner-manager's expected residual return, the equilibrium forgiveness is not sufficient to guarantee that the new debt level will be sustainable. This is immediate since, as noted 
above, $\bar{b}>\mathrm{H} / 2$, so it is possible for the new level of debt to exceed even H. Also, Figure 1 shows that $\underline{b}$ $>1 / 2 \mathrm{~L}$. Thus, equilibrium forgiveness is guaranteed to be insufficient in the event that the realization of the firm value is $\mathrm{L}$. (On the other hand, $\underline{\mathrm{b}}<1 / 2 \mathrm{H}$, so the new level of debt may be sustainable.) In practice, bankruptcy reorganization cannot guarantee that a firm will not subsequently experience financial distress (just as a firm that has not experienced financial distress in the past cannot guarantee that financial distress will not occur in the future). We discuss this issue at greater length in section 3.

\section{Additional Considerations in ACCORD}

The earlier section showed that the ACCORD scheme results in debt forgiveness and that the owner-manager could expect a positive residual return, which provides the vital incentive to operate the firm efficiently. This result arises from the uncertainty over the value of the firm. We now extend these results in several ways.

\section{A) Pre-Existing Seniority of Claims}

Example 2 is now altered to include junior creditors who have claims in addition to the two (senior) creditors. Since the payoffs to the two senior creditors do not depend on the junior creditors' claims, the optimal bidding strategy of senior creditors (described in Section II) would be unchanged. We now examine the junior creditor's bidding strategy.

Let $\mathrm{S}$ represent the sum of the senior creditors' bids. As was noted, $\mathrm{L} \leq 2 \underline{\mathrm{b}} \leq \mathrm{S}$ and $\mathrm{H}$ may exceed S. Consequently, the junior creditors face a residual value of 0 or $\max \{\mathrm{H}-\mathrm{S}, 0\}$, depending on whether the realized firm value is $\mathrm{L}$ or $\mathrm{H}$, respectively. Based on the equilibrium bidding from Section 2, junior creditors will bid $\mathrm{b}=1 / 2 \max \{\mathrm{H}-\mathrm{S}, 0\}$, which eliminates all positive expected residual returns for the owners.

It is Example 2's two-point distribution assumption that entirely eliminates the owners' expected residual returns. We now consider a continuous distribution example in which junior claimants expect to receive a positive expected return. In particular, with a pre-existing seniority structure, all senior creditor 
classes who are certain that they would be repaid, would bid no forgiveness. Only in the class where there is some probability of not being fully paid, would bids involve forgiveness as in Section 2. Their bidding will leave a positive expected return to the next most senior claimants, who will bid in a manner that offers a positive expected return to those junior to them, and so on down to the equityholders.

\section{Example 3:}

Suppose that it is commonly known by the creditors that the value of the firm, V, is uniformly distributed on $[0,1]$. Our analysis considers the two most-senior creditors, who are owed identical amounts that exceed $\$ 1$ in total. Appendix 2 determines the symmetric equilibrium in which both creditors bid an amount $\mathrm{b}$ that they are willing to accept according to the following cumulative distribution function:

$$
\mathrm{G}(\mathrm{b})=\left\{\begin{array}{cc}
-\frac{\mathrm{k}_{1}}{2 \mathrm{~b}^{2}}-0.5 \ln (\mathrm{b})+\mathrm{k}_{2} & \text { if } \mathrm{b} \in\left(\underline{\mathrm{b}, \frac{1}{2}}\right) \\
2+\mathrm{k}_{2}-0.5 \ln (1-\mathrm{b}) & \\
+\frac{\mathrm{k}_{1} \ln \left(\frac{1+\sqrt{1-2(1-\mathrm{b})^{2}}}{\sqrt{2}(1-\mathrm{b})}\right)+\sqrt{2} \sin ^{-1}(\sqrt{2}(1-\mathrm{b}))}{\sqrt{1-2(1-b)^{2}}} & \text { if } \mathrm{b} \in\left(\frac{1}{2}, \bar{b}\right) \\
+\frac{0.5 \tanh ^{-1}\left(-\sqrt{1-2(1-b)^{2}}\right)+\mathrm{k}_{3} \sqrt{2}}{\sqrt{1-2(1-b)^{2}}}, &
\end{array}\right.
$$

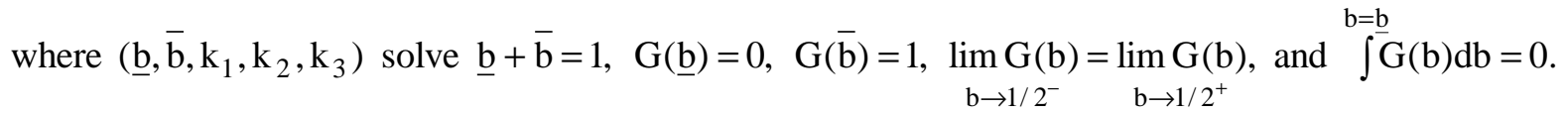

By numerical solution, $\left(\underline{\mathrm{b}}, \overline{\mathrm{b}}, \mathrm{k}_{1}, \mathrm{k}_{2}, \mathrm{k}_{3}\right) \approx(0.2532,0.7468,0.2211,1.0379,-1.8327)$.

Thus, in equilibrium, the creditors bid a reduced level of debt, b, according to the cdf G(b), which is graphed in Figure 3. The range of bids is $[\underline{b}, \bar{b}]=[0.2532,0.7468]$. Two properties of the equilibrium 
are immediate. First, since creditors are indifferent among all bids between $\underline{b}$ and $\bar{b}$ and since bidding $\underline{b}$ guarantees that one is the senior claimant, each creditor's expected return in equilibrium is:

$$
\underline{b} \cdot(1-F(\underline{b}))+\int_{v=0}^{b} \operatorname{vdF}(v)=0.22115 \text {. }
$$

For a creditor that bids $\underline{b}$, the two terms above represent, respectively, a payment of $\underline{b}$ when the realized value of the firm exceeds $\underline{b}$ and a payment equal to the full value of the firm when that value is less than b. Thus, the creditors together expect a return of 0.44223 , and leave 0.05777 or $11.55 \%$ of the expected firm value to the more junior claimants.

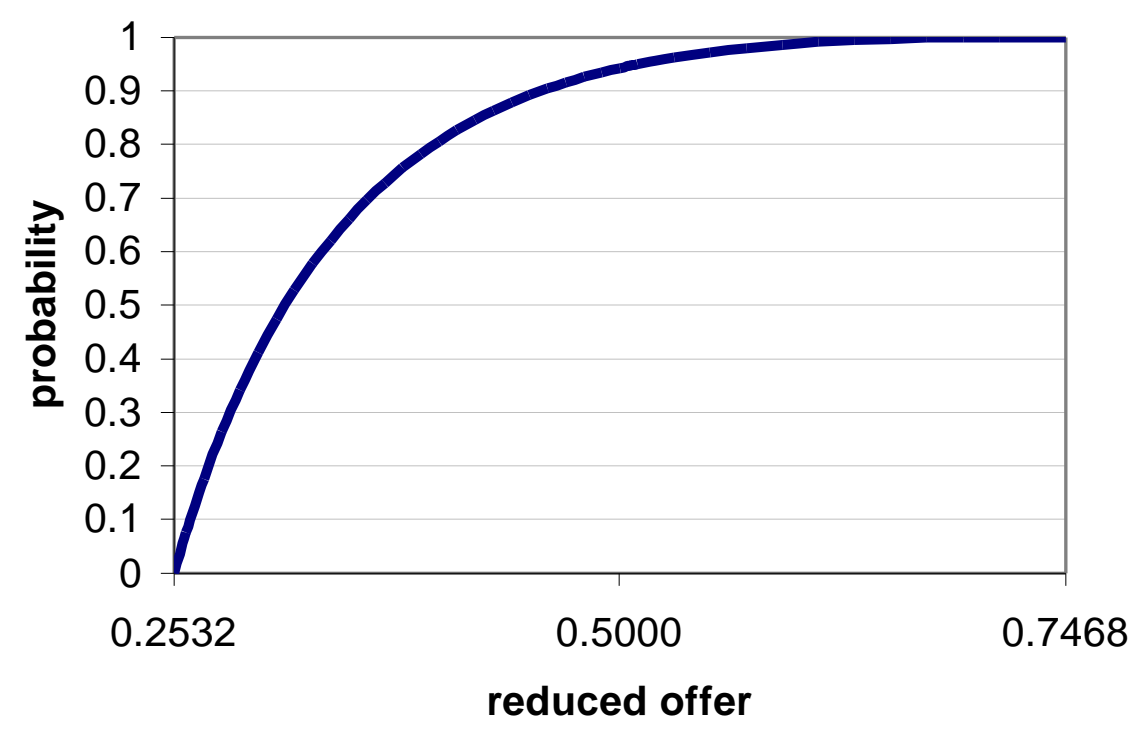

Figure 3: Cumulative distribution function for Example 3's symmetric equilibrium bidding strategy.

Since $\underline{b}=0.2532$, a second property of the equilibrium is that the two creditors together are guaranteed to bid more than 0.5 , the expected value of the firm. It can be shown that each creditor bids 0.3399 on average. With an upper range of $\bar{b}=0.7468$, it is immediate that the creditors together may demand more than 1.0, the highest possible value of the firm. The likelihood of that event is only $1.38 \%$, 
though. Thus, with probability $98.62 \%$, junior claimants receive a positive level of expected residual return.

This pattern of progressively smaller but positive expected returns to the progressively more junior creditors violates absolute priority, but it helps the functioning of ACCORD. In any class, creditors need both uncertainty and some expected return as an incentive to compete for a better position in their segment of the queue; otherwise, they have no incentive to forgive, which would adversely affect the outcome of ACCORD. Alternatively, if someone (the government?) could extinguish the claims of the very junior creditors, owners would be assured of an even greater positive expected return.

\section{B) Creditors with Private Information}

Section 2 assumed that the creditors share a common belief about the probability distribution of the value of the firm. In practice, creditors may have different information and may interpret the same information about the firm differently. In this subsection we consider an example with two creditors, each with private information. We show a Bayesian-Nash equilibrium in which a creditor who is more optimistic about the firm's prospects tends to forgive less and more likely to become the junior creditor.

\section{Example 4}

Suppose that the value of the firm is $V=V_{1}+V_{2}$. Both creditors share a common belief that the random variables $V_{1}$ and $V_{2}$ are independent, that $V_{1}$ takes on the values 0 or 1 , each with probability $1 / 2$, and that $\mathrm{V}_{2}$ is 0 or 1 , each with probability $1 / 2$. Assume also that creditor $\mathrm{j}$ privately observes $\mathrm{v}_{\mathrm{j}}$, the realization of $\mathrm{V}_{\mathrm{j}, \mathrm{j}}=1,2$. Therefore, creditor $\mathrm{j}$ who observes 0 realizes that the firm is worth 0 or 1 , both equally likely, and creditor $\mathrm{j}$ who observes 1 knows that the firm is worth 1 or 2 , both with probability $1 / 2$.

The Bayesian-Nash Equilibrium has creditor $\mathrm{j}$ who observes $\mathrm{v}_{\mathrm{j}}=0$ bid draw a bid on the interval $[a, 1)$ according to the cumulative distribution function:

$$
\mathrm{G}_{0}(\mathrm{~b})=2+\frac{\mathrm{k}_{1}}{\sqrt{2 \mathrm{~b}-1}},
$$

or bid $b=1$ with probability $1-G_{0}(1)$. Also, creditor $j$ who observes $v_{j}=1$ draws a bid $b$ according to the cumulative distribution function: 


$$
G_{1}(b)= \begin{cases}1+\frac{k_{2}}{\sqrt{2 b-1}} & \text { for } b \in[a, 1) \\ 1+k_{2} & \text { for } b \in[1, c] \\ 2+\frac{k_{3}}{\sqrt{b-1}}-\frac{k_{2}}{2 \sqrt{2(b-1)}} \sin ^{-1}(5-4 b) & \text { for } b \in(c, 2-a] .\end{cases}
$$

Finally, $\left(a, c, k_{1}, k_{2}, k_{3}\right)$ solve $G_{0}(a)=0, G_{1}(a)=0, G_{1}(1)=G_{1}(c), G_{1}(2-a)=1$, and

$$
\mathrm{a}=\frac{1}{2} \int_{\mathrm{b}_{2}=\mathrm{a}}^{1}\left(1-\mathrm{b}_{2}\right) \mathrm{dG}_{0}\left(\mathrm{~b}_{2}\right)+\frac{1}{2}\left[\mathrm{c}\left(1-\mathrm{G}_{1}(\mathrm{c})+\mathrm{G}(2-\mathrm{c})\right)+\int_{\mathrm{b}_{2}=2-\mathrm{c}}^{1}\left(2-\mathrm{b}_{2}\right) \mathrm{dG}_{1}\left(\mathrm{~b}_{2}\right)\right] .
$$

Condition 1 ensures that creditor $\mathrm{j}$ who observes $\mathrm{v}_{\mathrm{j}}=1$ receives the same expected return with a bid in the interval $[\mathrm{a}, 1)$ as with a bid in the interval $[\mathrm{c}, 2-\mathrm{a}]$. By numerical solution,

$\left(\mathrm{a}, \mathrm{c}, \mathrm{k}_{1}, \mathrm{k}_{2}, \mathrm{k}_{3}\right)=(0.6379,1.0510,-1.0503,-.5252,-.5154)$.

Thus, creditor $j$ who observes $v_{j}=0$ randomizes on the interval $[a, 1]$ with an atom at $b=1$. Creditor $j$ who observes $\mathrm{v}_{\mathrm{j}}=1$ randomizes on the intervals $[\mathrm{a}, 1)$ and $[\mathrm{c}, 2-\mathrm{a}]$. A creditor who observes 0 realizes an expected return of $\mathrm{a} / 2=0.3189$ and a creditor who observes 1 has an expected return of $\mathrm{a}=0.6379$. It follows that each creditor's ex ante expected return is $1 / 2(a / 2+a)=0.4784$. This gives the two creditors a total expected return of 0.9568 . Given that the firm has an expected value of 1.0 , the owner-managers receive an expected residual return of 0.0432 , or $4.32 \%$ of the firm value. (A proof of this equilibrium is not supplied, since it follows closely the proofs associated with Examples 2 and 3.)

The expected bid by a creditor observing 0 is:

$$
\int_{b=a}^{1} b_{b} G_{0}(b)+1 \cdot(1-G(1))=0.7745
$$

and the expected bid by a creditor observing 1 is:

$$
\int_{b=a}^{1} b d G_{1}(b)+\int_{b=c}^{2-a} b^{-a} G_{1}(b)=0.9497
$$




\section{C) Government-creditor and Noncompetitive Bids}

Many East Asian governments now hold (directly or indirectly) substantial claims against financially distressed private firms. The governments have taken over, or substantially control the domestic banks whose non-performing loans far exceed their capital. Banks' claims on private, financially distressed firms (whether residing in the intervened banks, or in bank restructuring agencies, or asset management companies) are substantial and are not controlled by the government. While the government agent could bid like other creditors, given its size and vulnerability to making politically motivated bids, we suggest that these claims be reduced by the weighted average ${ }^{7}$ of the other bids. Such "non-competitive bids" (to use the misleading term from the auction for U.S. Treasury Bills) would avoid politicizing the auction, and may also be permitted for other small creditors who may be at an informational disadvantage.

\section{Implementation and Conclusions}

A common reaction to unusual solutions is "Has it been done before?" and the absence of a direct precedent offers little comfort that it would work as promised. Unprecedented problems (systemic bankruptcy on this scale) cannot have tested solutions; but while the ACCORD is still a proposal, auctions of analogous importance and complexity are increasingly widespread. For example, for the Federal Communications Commission's airwaves auction, there is now an extensive literature that both describes the important role that theoretical work on simple auction models played in the design of this extremely complex auction and examines its success (e.g., Cramton 1995, 1997). Another example is the auction by Thailand's Financial Restructuring Agency of the loan portfolios of the finance companies that were closed in 1997.

An important advantage of the ACCORD is to prevent the politics from distorting the renegotiations of debts. East Asian governments and courts already have a reputation for being 
susceptible to the influence of powerful and wealthy business interests. With the taxpayers bearing much of the losses (through the government guarantee of banking deposits), some of the well-connected debtors may enjoy an unwarranted reduction in debts in negotiations with government agents (e.g. the asset management companies or bank restructuring agencies which hold the claims). Even if this did not occur, the fear of such an accusation would stymie any bureaucrat negotiating unpaid claims. An auction protects the honest civil servant because the government-controlled claims could be reduced by the weighted average of other bids.

Our model is a static one since it assumes that the value of the firm is realized after the auction and that this value is then distributed, according to the ACCORD outcome, to the claimants. In practice, there is a need to understand the dynamics following the ACCORD auction. One approach is to require all creditors ${ }^{9}$ to forfeit their right to file bankruptcy or liquidation petitions for, say, 5 years. Owners also agree to forgo any cash dividends or payouts during this period and, if the reduced debts are not fully discharged by the end of the 5 years, to automatic liquidation. ${ }^{10}$ The automatic liquidation clause protects creditors against the firm accumulating cash surpluses (which may have genuine business reasons) instead of servicing the debts of those in the creditor queue.

The deferred debts accrue interest at specified rates ${ }^{11}$, and whenever these debts have been fully discharged, the court declares that the firm is no longer under its aegis and it is free to operate unfettered. If the (reduced) debts have not been fully discharged by the end of the 5 years specified, the firm is liquidated automatically. (This too could be by auction with the owners and creditors free to bid.)

7 It could also be that the government's claims and queue positions are assigned to match perfectly the proportionate reductions and queue positions of the other creditors. Thus, rather than the government's claims appearing as a bulge in the middle of the queue, its claims could be uniformly spread over the queue.

${ }^{8}$ The requisite supermajority would be the same as that required for a cram down under the bankruptcy law: generally a simple majority within each class and two-thirds or three-quarters of the aggregate. This would also bind any new creditors who subsequently lend the firm money (suitable clauses could be inserted into the loan contract).

${ }^{9}$ Since the requisite super-majority needed for any cram down under conventional bankruptcy have approved both the plan and the decision to enter the ACCORD scheme, this can be made binding on the dissenters.

${ }^{10}$ Depending on the company law, a shareholder meeting may have to approve the management decision. The meeting may also be required to approve a curtailed role for the Board of Directors and managers to protect them against shareholder suits (although few countries are as litigious as the United States). 
One likely dispute is if the firm accumulates cash without paying any of the deferred creditors. While many owners are unlikely to needlessly accumulate a cash horde, some may; but cash is often needed to operate the business, and perhaps even expand. Having the judge adjudicate this would generate endless disputes which would tie the courts and the parties involved into knots. Instead, the automatic liquidation protects creditors who have a right to this cash. Furthermore, creditors may trade their claims at any time ${ }^{12}$; so regardless of their position in the queue, creditors could cash in their claims (albeit at a price different from their reduced claim).

While firms may not distributing cash (except as specified to the head of the creditor queue), they are free to raise additional funds through asset sales, new equity or borrowings. These new claims cannot come ahead of existing claims, and may not be serviced before all the deferred claims outstanding are fully discharged. Any new equity would be in the same class as the old equity (at the very end of the queue); but a new loan would be behind all other loans (although ahead of the equity). Note this difference from conventional bankruptcy filing (where new loans come before pre-filing loans); and this is because the old creditors have already reduced their claims.

Putting new borrowings at the back of the creditor queue would not be detrimental to the continued operations of the firm or disadvantageous to the new creditor. Recall that the firm is not obligated to make any cash payment; so its ability to finance its continued operations is considerably greater. The firm may also discharge all of its outstanding debts at any time; so if the new lenders or investors find the restrictions onerous, the firm could use the proceeds to discharge the outstanding debts to the deferred creditors and operate unfettered by the rules of the ACCORD.

Finally, ACCORD differs from other market based schemes proposed in the literature in that it specifically does not allow for a change in control or a dilution of ownership. Rather than ask, as Bebchuck does in his pioneering proposal, which class of creditors should get the firm, ACCORD assures

\footnotetext{
${ }^{11}$ Interest accrual does not benefit creditors per se (for the bids compensate for this); but if interest did not accrue, firms would have an incentive to accumulate cash and only pay just before the 5 year deadline to avoid liquidation.

${ }^{12}$ When they do trade, they have to inform the auditor so the cheque could be sent to the correct claimant; but neither the firm nor the court need to be informed.
} 
the owners that they would continue to own and operate the firm, and instead has creditors bid against each other by trading off how much they are willing to collect against how long they are willing to wait. This is an attractive feature of ACCORD for the current East Asian situation, since creditors are ill suited to operate the myriad firms that are staggering under large debts but creditor rights are not enforced in practice. Creditors may benefit from owner-managers being assured that they will remain in control and with improved incentives to operate the firm through the reductions in the face value of the debt claims. 


\section{References}

Aghion, P., O. Hart and J. Moore (1992), “The Economics of Bankruptcy Reform,” Journal of

Law, Economics and Organization, Vol. 8, Number 3 (October), 523-546.

(1995), “Insolvency Reform in the U.K., A Revised Proposal," Insolvency law

\& Practice, Vol.11, No.3, pp67-74.

Bebchuk, Lucian Ayre (1988), “A New Approach to Corporate Reorganizations," Harvard Law

Review, Vol. 101 (February), 775-804.

Berkovitch, Elazar and Ronen Israel (1999), “Optimal Bankruptcy Laws Across Different

Economic Systems," Review of Financial Studies, Summer, 12(2), 347-377.

Cramton, Peter, "Money Out of Thin Air: The Nationwide Narrowband PCS Auction,” Journal of

Economics and Management Strategy, 1995, 4, 267-343.

Cramton, Peter, "The FCC Auctions: An Early Assessment," Journal of Economics and

Management Strategy, 1997, 6, 431-495.

Gilson, S. (1995), “Transactions Costs and Capital Structure Choice: Evidence From Financially

Distressed Firms," working paper, Harvard Business School.

Hart, Oliver, Rafael La Porta Drago, Florencio Lopez-de-Silanes, and John Moore (1997), “A

New Bankruptcy Procedure that Uses Multiple Auctions," European Economic Review, April, 41, 461-

473.

LoPucki, Lynn and William Whitford (1993), "Corporate Governance in the Bankruptcy

Reorganization of Large, Publicly Held Companies," University of Pennsylvania Law Review, January, $141(3), 669-800$.

Schleifer, A. and R. Vishny (1992), “Liquidation Value and Debt Capacity: A Market

Equilibrium Approach," Journal of Finance, Vol.47, No.4

Stiglitz, J. (1999), “Reforming the Global Economic Architecture: Lessons from Recent Crises,”

Journal of Finance, 1508-1521. 
APPENDIX 1: Equilibrium of Example 2

The ACCORD equilibrium of Example 2 has four cases. Since the proofs for the four cases are similar, we treat only case 1 .

Suppose creditor 2 bids $\mathrm{b}_{2}$ according to $\mathrm{G}\left(\mathrm{A}\right.$ for $\mathrm{L}^{*}<\mathrm{L}<100$. Bidding $\mathrm{b} \leq \underline{\mathrm{b}}$, creditor 1 realizes a certain return of $b$. Therefore, creditor 1 strictly prefers bidding $\underline{b}$ to any $b<\underline{b}$. For $b \in[\underline{b}, H / 2]$, creditor 1's expected payoff is:

$$
P(b) \equiv b(1-G(b))+\frac{1}{2} \int_{b_{2}=\underline{b}}^{b}\left(L-b_{2}\right) d G\left(b_{2}\right)+\frac{1}{2} b G(b)
$$

The first term deals with the event that creditor 1 bids less than creditor 2, becomes senior creditor, and is paid $\mathrm{b}$ whether the firm value is $\mathrm{L}$ or $\mathrm{H}$. The second and third terms treat the event that creditor bids more than creditor 2, and so becomes the junior creditor. In the second term, the value is L so there is only L$\mathrm{b}_{2}$ available to creditor 1 . In the third term, the value is $\mathrm{H}$, which is sufficient to fully pay the junior creditor. Integrating by parts gives:

$$
P(b)=b-\frac{1}{2} b G(b)+\frac{1}{2}(L-b) G(b)+\frac{1}{2} \int_{b_{2}=\underline{b}}^{b} G\left(b_{2}\right) d b_{2}
$$

which reduces to:

$$
\mathrm{P}(\mathrm{b})=\mathrm{L}-\underline{\mathrm{b}}-\frac{\mathrm{c}_{1} \sqrt{2 \underline{\mathrm{b}-\mathrm{L}}}}{2}=\underline{\mathrm{b}},
$$

where the last equality follows since the condition $G_{1}\left(\underline{b}, c_{1}\right)=0$ means that $c_{1}=-2 \sqrt{2 \underline{b}-L}$.

Now consider $b \in[H / 2, \bar{b}]$, in which case creditor 1 's expected return is:

$$
P(b) \equiv b(1-G(b))+\frac{1}{2} \int_{b_{2}=\underline{b}}^{b}\left(L-b_{2}\right) d G\left(b_{2}\right)+\frac{1}{2}\left\{\int_{b_{2}=\underline{b}}^{H-b} b d G\left(b_{2}\right)+\int_{b_{2}=H-b}^{b}\left(H-b_{2}\right) d G\left(b_{2}\right)\right\} .
$$

This expression differs from $\mathrm{P}(\mathrm{b})$ for $\mathrm{b} \in[\underline{\mathrm{b}}, \mathrm{H} / 2]$ in the last term. Here, if creditor 1 is junior and the value is $H$, then creditor 1 receives $b$ only if $b_{2}$ is less than $H-b$; otherwise, creditor 1 receives $H-b_{2}$. Plugging in $\mathrm{G}(\mathrm{b})$ gives: 


$$
\begin{aligned}
\mathrm{P}(\mathrm{b})= & 200-\mathrm{H}-\underline{\mathrm{b}}+\frac{\mathrm{c}_{1}}{2}(2 \sqrt{\mathrm{H}-\mathrm{L}}-\sqrt{2 \mathrm{H}-\mathrm{L}-2 \mathrm{~b}}-\sqrt{2 \underline{b}-\mathrm{L}})-\frac{\sqrt{2 \mathrm{~b}-100}}{4}\left(4 \mathrm{c}_{2}-\mathrm{c}_{1} \sin ^{-1}\left[\frac{500-3 \mathrm{~L}-4 \mathrm{~b}}{300-3 \mathrm{~L}}\right]\right) \\
& +\int_{\mathrm{b}_{2}=\mathrm{H} / 2}^{\mathrm{b}} \frac{4 \mathrm{c}_{2}-\mathrm{c}_{1} \sin ^{-1}\left[\frac{500-3 \mathrm{~L}-4 \mathrm{~b}_{2}}{300-3 \mathrm{~L}}\right]}{4 \sqrt{2 \mathrm{~b}_{2}-100}} \mathrm{db}_{2} .
\end{aligned}
$$

We first show that $\mathrm{P}(\mathrm{H} / 2)=\underline{\mathrm{b}}$ and then demonstrate that $\mathrm{P}^{\prime}(\mathrm{b})=0$ for $\mathrm{b}>\mathrm{H} / 2$.

$$
\begin{aligned}
& \mathrm{P}(\mathrm{H} / 2)=200-\sqrt{\mathrm{H}-100}\left[\mathrm{c}_{2}-\frac{\mathrm{c}_{1}}{4} \sin ^{-1}(1 / 3)\right]-\underline{\mathrm{b}}-\mathrm{H}+\frac{\mathrm{c}_{1}}{2}(\sqrt{\mathrm{H}-\mathrm{L}}-\sqrt{2 \underline{\mathrm{b}}-\mathrm{L}}) \\
& =200-\frac{\mathrm{c}_{1} \sqrt{\mathrm{H}-100}}{\sqrt{2}}-\underline{\mathrm{b}}-\mathrm{H}+\frac{\mathrm{c}_{1}}{2}(\sqrt{\mathrm{H}-\mathrm{L}}-\sqrt{2 \underline{\mathrm{b}}-\mathrm{L}}) \quad \text { since } \mathrm{c}_{2}=\mathrm{c}_{1}\left[\frac{1}{\sqrt{2}}+\frac{1}{4} \sin ^{-1}(1 / 3)\right] \\
& =200-\frac{\mathrm{c}_{1}}{2} \sqrt{\mathrm{H}-\mathrm{L}}-\underline{\mathrm{b}}-\mathrm{H}+\frac{\mathrm{c}_{1}}{2}(\sqrt{\mathrm{H}-\mathrm{L}}-\sqrt{2 \underline{b}-\mathrm{L}}) \\
& =200-\underline{\mathrm{b}}-\mathrm{H}-\frac{\mathrm{c}_{1}}{2} \sqrt{2 \underline{\mathrm{b}}-\mathrm{L}} \\
& =\underline{\mathrm{b}} \quad \text { since } \mathrm{c}_{1}=-2 \sqrt{2 \underline{b}-\mathrm{L} .}
\end{aligned}
$$

We now determine $\mathrm{P}^{\prime}(\mathrm{b})$ for $\mathrm{b} \in[\underline{\mathrm{b}}, \mathrm{H} / 2]$.

$$
\begin{aligned}
& P^{\prime}(b)=\frac{-c_{1} \sqrt{2 b-100}}{\sqrt{(300-3 L)^{2}-(500-3 L-4 b)^{2}}}+\frac{c_{1}}{2 \sqrt{2 H-L-2 b}} \\
& =\frac{-c_{1} \sqrt{2 b-100}}{\sqrt{(300-3 L)^{2}-(300-3 L+200-4 b)^{2}}}+\frac{c_{1}}{2 \sqrt{2 H-L-2 b}} \\
& =\frac{-c_{1} \sqrt{2 b-100}}{\sqrt{-4(300-3 L)(100-2 b)-4(100-2 b)^{2}}}+\frac{c_{1}}{2 \sqrt{2 H-L-2 b}} \\
& =\frac{-c_{1}}{2 \sqrt{400-3 L-2 b}}+\frac{c_{1}}{2 \sqrt{400-3 L-2 b}}=0 .
\end{aligned}
$$


Thus, $\mathrm{P}(\mathrm{b})=\underline{\mathrm{b}}$ for $\mathrm{b} \in[\underline{\mathrm{b}}, \overline{\mathrm{b}}] . \mathrm{P}(\mathrm{b})=\underline{\mathrm{b}}$ for $\mathrm{b}>\overline{\mathrm{b}}$, too, since $\overline{\mathrm{b}}=\mathrm{H}-\underline{\mathrm{b}}$ means that bidding $\mathrm{b}>\overline{\mathrm{b}}$ has the same return as bidding $\mathrm{b}=\overline{\mathrm{b}}$.

Finally, this analysis has assumed that $\underline{\mathrm{b}}<\mathrm{L}$, which occurs for $\mathrm{L}>\mathrm{L}^{*}$.

We have shown that, for case 1 and against creditor 2 using G(A, creditor 1 cannot do better than to bid on $[\underline{b}, \bar{b}]$. Thus, $G(A$ is a best response for creditor 1 , which means that it is an equilibrium for both creditors to use $G(A . \ddot{A}$ 


\section{APPENDIX 2: Equilibrium of Example 3}

Recall that $\mathrm{V} \sim \mathrm{U}[0,1]$. We will determine a symmetric mixed-strategy bidding equilibrium for the creditors. Let $\mathrm{G}(\mathrm{b})$ denote the cumulative distribution function and let $\mathrm{g}(\mathrm{b})$ be the probability density function. The range of bids is $[\underline{b}, \bar{b}]$, with $\underline{b}+\bar{b}=1$. This follows since a creditor cannot gain from bidding more than $1-\underline{b}$ if the lowest that the other creditor will bid is $\underline{b}$. To determine $G(b)$, assume that creditor 2 bids $b_{2}$ using $G(\cdot)$ and first consider creditor 1's expected return with a bid $b \in(\underline{b}, 0.5)$ :

$$
\left(\mathrm{b}(1-\mathrm{b})+\int_{\mathrm{v}=0}^{\mathrm{b}} \mathrm{vdv}\right) \cdot\left(1-\mathrm{G}(\mathrm{b})+\int_{\mathrm{b}_{2}=\underline{\mathrm{b}}}^{\mathrm{b}} \int_{\mathrm{v}=\mathrm{b}_{2}}^{\mathrm{b}+\mathrm{b}_{2}}\left(\mathrm{v}-\mathrm{b}_{2}\right) \operatorname{dvdG}\left(\mathrm{b}_{2}\right)+\int_{\mathrm{b}_{2}=\underline{\mathrm{b}}}^{\mathrm{b}} \int_{\mathrm{v}=\mathrm{b}+\mathrm{b}_{2}}^{1} \operatorname{bdvdG}\left(\mathrm{b}_{2}\right) .\right.
$$

The first term above treats the case of creditor 1 bidding less than creditor 2, which occurs with probability $1-G(b)$. In this case, creditor 1 realizes $b$ if the value of the firm exceeds $b$ and the full value of the firm otherwise. The other terms cover the case when creditor 2 bids less than creditor 1 . Term 2 deals with the firm value being sufficiently low that creditor 1 receives only $v-b_{2}$ while term 3 has the firm value high enough that creditor 1 receives $b$. If creditor 1 is to be indifferent among all the bids $\mathrm{b} \in(\underline{\mathrm{b}}, 0.5)$, then the derivative of $(2.1)$ is zero:

$$
0=(1-b) \cdot(1-G(b))-g(b) \cdot\left(b(1-b)+\int_{v=0}^{b} v d v-\int_{v=b}^{2 b}(v-b) d v-\int_{v=2 b}^{1} b d v\right)+\int_{b_{2}=\underline{b}}^{b}\left(1-b-b_{2}\right) d G\left(b_{2}\right)
$$

With $\mathrm{H}(\mathrm{b}) \equiv \int_{\mathrm{b}_{2}=\underline{\mathrm{b}}}^{\mathrm{b}} \mathrm{G}\left(\mathrm{b}_{2}\right) \mathrm{db}_{2}$, equation (2.2) to:

$$
b^{2} H^{\prime \prime}(b)+b H^{\prime}(b)-H(b)=1-b .
$$

Differentiating the second-order differential equation (2.3) with respect to $\mathrm{b}$ gives a first-order differential equation:

$$
H^{\prime \prime \prime}(b)+3 b^{-1} H^{\prime \prime}(b)=-b^{-2}
$$

The solution of (2.4) is:

$$
\mathrm{g}(\mathrm{b})=\mathrm{H}^{\prime \prime}(\mathrm{b})=\mathrm{k}_{1} \mathrm{~b}^{-3}-0.5 \mathrm{~b}^{-1}
$$


Therefore, as was to be shown, for $\mathrm{b} \in(\underline{b}, 0.5)$ :

$$
\mathrm{G}(\mathrm{b})=-0.5 \mathrm{k}_{1} \mathrm{~b}^{-2}-0.5 \ln (\mathrm{b})+\mathrm{k}_{2} \text {. }
$$

We next consider creditor 1 's expected return from a bid $b \in(0.5, \bar{b})$ :

$$
\begin{aligned}
(\mathrm{b}(1-\mathrm{b}) & \left.+\int_{\mathrm{v}=0}^{\mathrm{b}} \mathrm{vdv}\right) \cdot\left(1-\mathrm{G}(\mathrm{b})+\int_{\mathrm{b}_{2}=\underline{\mathrm{b}}}^{1-\mathrm{b}} \int_{\mathrm{v}=\mathrm{b}_{2}}^{\mathrm{b}+\mathrm{b}_{2}}\left(\mathrm{v}-\mathrm{b}_{2}\right) \operatorname{dvdG}\left(\mathrm{b}_{2}\right)\right. \\
& +\int_{\mathrm{b}_{2}=1-\mathrm{b}}^{\mathrm{b}} \int_{\mathrm{v}=\mathrm{b}_{2}}^{1}\left(\mathrm{v}-\mathrm{b}_{2}\right) \operatorname{dvdG}\left(\mathrm{b}_{2}\right)+\int_{\mathrm{b}_{2}=\underline{\mathrm{b}}}^{1-\mathrm{b}} \int_{\mathrm{v}=\mathrm{b}+\mathrm{b}_{2}}^{1} \operatorname{bdvdG}\left(\mathrm{b}_{2}\right) .
\end{aligned}
$$

The first term deals with creditor 1 bidding less than creditor 2 . If creditor 1 bids more than creditor 2, thereby becoming the junior creditor, then creditor 1 receives zero if $\mathrm{v}<\mathrm{b}_{2}$, receives $\mathrm{v}-\mathrm{b}_{2}$ if $\mathrm{v}$ is between $b_{2}$ and $\min \left\{b+b_{2}, 1\right\}$ (see terms 2 and 3 ), and receives $b$ if $v>b+b_{2}$ (see term 4 ). If creditor 1 is indifferent among all bids in this interval, then the derivative of (2.6) is zero:

$$
0=(1-b) \cdot(1-G(b))-g(b) \cdot\left(b(1-b)+\int_{v=0}^{b} v d v-\int_{v=b}^{1}(v-b) d v\right)+\int_{b_{2}=\underline{b}}^{1-b}\left(1-b-b_{2}\right) d G\left(b_{2}\right)
$$

Using integration by parts, (2.7) reduces to:

$$
0=(1-b) \cdot(1-G(b))+g(b) \cdot\left(0.5-2 b+b^{2}\right)+\int_{b_{2}=\underline{b}}^{1-b} G\left(b_{2}\right) d b_{2}
$$

Since the range of bids in the integral term of $(2.8)$ is in the interval $(\underline{b}, 0.5)$, then $(2.5)$ can be used to reduce $(2.8)$ to:

$$
\begin{aligned}
0=-(1 & -\mathrm{b}) \cdot \mathrm{G}(\mathrm{b})+\mathrm{g}(\mathrm{b}) \cdot\left(0.5-2 \mathrm{~b}+\mathrm{b}^{2}\right)+\mathrm{k}_{2}(1-\mathrm{b}-\underline{\mathrm{b}}) \\
& +0.5((1-\mathrm{b}) \ln (1-\mathrm{b})+1-\mathrm{b}-\underline{\mathrm{b}} \ln (\underline{\mathrm{b}})+\underline{\mathrm{b}})+0.5 \mathrm{k}_{1}\left(\frac{1}{1-\mathrm{b}}-\frac{1}{\mathrm{~b}}\right) .
\end{aligned}
$$

Solving this first-order linear differential equation gives the indicated expression for $G(b)$ in the range $\mathrm{b} \in(0.5, \bar{b})$ 
The five constants $\left(\underline{\mathrm{b}}, \overline{\mathrm{b}}, \mathrm{k}_{1}, \mathrm{k}_{2}, \mathrm{k}_{3}\right)$ solve the following equations: $\underline{\mathrm{b}}+\overline{\mathrm{b}}=1, \mathrm{G}(\underline{\mathrm{b}})=0, \mathrm{G}(\overline{\mathrm{b}})=1$, $\lim _{b \rightarrow 1 / 2^{-}} G(b)=\lim _{b \rightarrow 1 / 2^{+}} G(b)$, and $\int^{b=\underline{b}} G(b) d b=0$. Thus, assuming creditor 2 uses $G(b)$ on $[\underline{b}, \bar{b}]$, creditor 1 's

expected return is constant across $[\underline{b}, \bar{b}]$, and it is fairly simple to show that creditor 1 has no interest in venturing outside $[\underline{b}, \bar{b}]$. Thus, both bidders using $G(b)$ is a symmetric Nash equilibrium $\ddot{A}$ 